\title{
Fine-structural analysis of black band disease- infected coral reveals boring cyanobacteria and novel bacteria
}

\author{
Aaron W. Miller ${ }^{1, *}$, Patricia Blackwelder ${ }^{2,3,4}$, Husain Al-Sayegh $^{2,3}$, \\ Laurie L. Richardson ${ }^{1}$ \\ ${ }^{1}$ Department of Biological Sciences, Florida International University, Miami, Florida 33199, USA \\ ${ }^{2}$ University of Miami Center for Advanced Microscopy (UMCAM), Miami, Florida 33124, USA \\ ${ }^{3}$ Marine Geology and Geophysics, University of Miami, Miami, Florida 33149, USA \\ ${ }^{4}$ Nova Southeastern University Oceanographic Center, Dania, Florida 33004, USA
}

\begin{abstract}
Examination of coral fragments infected with black band disease (BBD) at the fine- and ultrastructural levels using scanning (SEM) and transmission electron microscopy (TEM) revealed novel features of the disease. SEM images of the skeleton from the host coral investigated (Montastraea annularis species complex) revealed extensive boring underneath the BBD mat, with cyanobacterial filaments present within some of the bore holes. Cyanobacteria were observed to penetrate into the overlying coral tissue from within the skeleton and were present throughout the mesoglea between tissue layers (coral epidermis and gastrodermis). A population of novel, as yet unidentified, small filamentous bacteria was found at the leading edge of the migrating band. This population increased in number within the band and was present within degrading coral epithelium, suggesting a role in disease etiology. In coral tissue in front of the leading edge of the band, cyanobacterial filaments were observed to be emerging from bundles of sloughed-off epidermal tissue. Degraded gastrodermis that contained actively dividing zooxanthellae was observed using both TEM and SEM. The BBD mat contained cyanobacterial filaments that were twisted, characteristic of negative-tactic responses. Some evidence of boring was found in apparently healthy control coral fragments; however, unlike in BBD-infected fragments, there were no associated cyanobacteria. These results suggest the coral skeleton as a possible source of pathogenic BBD cyanobacteria. Additionally, SEM revealed the presence of a potentially important group of small, filamentous BBD-associated bacteria yet to be identified.
\end{abstract}

KEY WORDS: Black band disease $\cdot$ Coral disease $\cdot$ Boring cyanobacteria $\cdot$ Ultrastructure

\section{INTRODUCTION}

Research into coral diseases over the last 5 decades has revealed a high degree of complexity of those investigated. Many coral diseases exhibit similar signs, such as various disease states referred to collectively as 'white syndrome' (Bythell et al. 2004). Corals may have developed resistance to other coral pathogens, as is the case for the bacterial bleaching pathogen Vibrio shiloii (Rosenberg et al. 2009) and the white plague type II pathogen Aurantimonas coralicida (Richardson \&
Aronson 2002). Molecular studies have shown that specific bacterial sequences are present both in apparently healthy corals and in corals with different diseases, with unknown roles in each case (Rypien et al. 2010).

Black band disease (BBD) in particular exemplifies coral disease complexity and has been the subject of microbiological and microscopic investigation since the 1970s (Ducklow \& Mitchell 1979, Rützler et al. 1983, Carlton \& Richardson 1995, Cooney et al. 2002, Frias-Lopez et al. 2002, Barneah et al. 2007, Sekar et al. 
2008, Richardson et al. 2009, Sato et al. 2009). It has been known for decades that BBD is characterized by a complex, polymicrobial mat community in which gliding, filamentous cyanobacteria are volumetrically dominant (Rützler \& Santavy 1983). The mat migrates as a well-defined band across apparently healthy coral tissue, leaving behind freshly denuded skeleton, at an average rate of $3 \mathrm{~mm} \mathrm{~d}^{-1}$ (Rützler et al. 1983). The BBD cyanobacteria provide a structural framework within which a diverse microbial community is present (Rützler \& Santavy 1983). While the mechanisms that govern the initiation of BBD, as well as its mode of migration and tissue destruction, are still incompletely understood, it has recently been shown that sulfide (produced by BBD-associated sulfate-reducing bacteria) is required for initial infection (Richardson et al. 2009).

Multiple cyanobacterial species have been identified from colonies exhibiting macroscopic signs consistent with BBD infection (Cooney et al. 2002, Frias-Lopez et al. 2003, Sussman et al. 2006, Myers et al. 2007), along with other putative pathogens (Arotsker et al. 2009), which have been reported to be present on non-BBDdiseased corals as well (Jones et al. 2004). The natural reservoirs of BBD pathogens have not been elucidated, although different sources have been proposed. Cyanobacteria associated with BBD were detected (based on microscopic observation of characteristic morphology) in sediment-filled depressions on apparently healthy corals (Richardson 1997). However, none of these corals was observed to develop BBD. Molecular studies and disease surveys have also suggested an association with sewage contamination, fish or human pathogens, or terrestrial run-off (Frias-Lopez et al. 2002, Kaczmarsky et al. 2005, Sekar et al. 2008). While BBD has previously been demonstrated to be transmitted by fish (Aeby \& Santavy 2006). Sequences associated with human and fish pathogens were present in fewer than $4 \%$ of the sequences from 84 clone libraries constructed from BBD samples (Miller \& Richardson 2011). Field surveys comparing sewage-impacted and non-impacted sites revealed a higher incidence of BBD-infected colonies around impacted sites (Kaczmarsky et al. 2005). Molecular analysis of BBD samples from these same sites has shown that BBD composition differed significantly between impacted and nonimpacted sites (Sekar et al. 2008). These results suggest that sewage may provide opportunistic pathogens that could contribute to the disease, and that other factors such as nutrient loading may contribute to the increase in BBD prevalence.

A previous scanning electron microscopy (SEM) study of BBD showed that the BBD consortium consisted of a mixture of filamentous cyanobacteria and sulfide-oxidizing bacteria (Beggiatoa), with spiral bac- teria commonly embedded within the consortium (Ducklow \& Mitchell 1979). These authors proposed that BBD pathogens consumed the coral tissue and released zooxanthellae into the disease matrix. It was suggested that cyanobacteria may be necessary to initiate and maintain the disease, but that Beggiatoa present within the mat may be more intimately involved with the disease process due to the finding of cyanobacteria only in natural infections, and of Beggiatoa in both natural and artificial infections. In another BBD study, Rützler et al. (1983) found that in freshly infected coral tissue, bundles of cyanobacterial filaments were often separate from the main population and penetrated into the coral epidermis. These filaments then tunneled in all directions underneath the epidermis. It was suggested that this physical penetration is preceded by chemical degradation, with the mat migrating over the top of the degraded tissue, further degrading it, and resulting in a mat that contained decaying coral tissue (Rützler et al. 1983).

The purpose of the current study was to build upon these previous studies and, using electron microscopy, to examine the relationships between the BBD microbial mat microorganisms and the coral host, including infected and apparently healthy tissue and skeleton immediately in front of, underneath, and behind the migrating band. We also describe the condition of the host coral tissue and skeleton and characterize the fine structure of the BBD cyanobacterial matrix (mat fabric).

\section{MATERIALS AND METHODS}

Sample collection. Seven BBD-infected fragments and 2 apparently healthy control fragments from 8 colonies of the Montastraea annularis species complex were used for this study. Both naturally and artificially infected fragments were utilized. Fragments were infected by placing a small amount of freshly collected BBD mat directly onto the surface of corals (described below). This method results in a migrating BBD infection that lyses coral tissue the same way as BBD in the reef environment (Voss \& Richardson 2006, Richardson et al. 2009).

Of the BBD-infected fragments, 2 were collected by chiseling fragments from a BBD-infected colony on Algae Reef offshore of Key Largo, Florida (USA). Five other BBD-infected fragments were artificially infected in the laboratory, including 4 collected from Horseshoe Reef, Lee Stocking Island (LSI), Bahamas, and 1 from Algae Reef, Key Largo. The bands on the LSI fragments were allowed to migrate for $2 \mathrm{~d}$ prior to fixation, while the band from the Florida Keys migrated for $3 \mathrm{~d}$. To artificially infect fragments, they were held out of 
the water, gently abraded with the tip of a needleless syringe containing a BBD sample, and a small amount of the BBD mat was expelled onto the surface of the colony. After $\sim 30 \mathrm{~s}$, the mat was observed to adhere to the coral fragment surface, at which time the fragment was placed back into the aquarium. Two uninfected fragments from apparently healthy colonies, both collected at LSI, were used as controls. These fragments were abraded in the same manner, but were not inoculated with the BBD consortium.

Electron microscopy. Artificially infected coral fragments were prepared for SEM analysis by immersing them into $2 \%$ glutaraldehyde in $0.05 \mathrm{M}$ sodium cacodylate-buffered filtered seawater immediately after removal from experimental aquaria. BBD-infected fragments collected in situ on the reef were placed in $50 \mathrm{ml}$ Falcon tubes (underwater), and immersed in fixative immediately upon return to the boat. In the laboratory, the glutaraldehyde fixative was refreshed, and fragments were transferred to $0.05 \mathrm{M}$ sodium cacodylate filtered seawater buffer ( $3 \times$ for $10 \mathrm{~min}$ each), and post fixed in $1 \%$ osmium tetroxide in buffer for $30 \mathrm{~min}$. After an additional 3 buffer washes, the fragments were dehydrated in a graded series of ethanol, with a final concentration of $100 \%$. Small subfragments were then chiseled from both naturally and artificially infected fragments at the interface of the BBD mat and apparently healthy tissue for transmission electron microscopy (TEM). The remaining coral fragments were used for SEM, and were dried in hexamethyldisilazane (HMDS) at room temperature to outgas overnight. They were then mounted on carbon adhesive-covered aluminum stubs and coated with palladium. Samples were imaged in an FEI XL-30 ESEM/SEM fitted with an Oxford EDS system. For TEM analysis, the calcified subfragments in $100 \%$ ethanol were embedded in Spurr ${ }^{\mathcal{O}}$ embedding resin. A Sorval MT-2 ultramicrotome fitted with a diamond knife was used to cut sections of the coral and skeleton embedded in the blocks. Sections were placed on copper grids and stained with lead citrate (Reynolds 1963). Since calcified material was sectioned, uranyl acetate stain was not used because it is an acidic stain, and would dissolve the sectioned calcium carbonate skeleton, which was a subject of this study. Sections were imaged in a JEOL 1400 TEM equipped with a Gatan digital camera.

Analysis. BBD-infected coral tissue and skeleton fragments were examined extensively using SEM. Areas observed included the black band consortium (surface and interior of the mat), the coral/band interface (leading and trailing edges), exposed coral skeleton (the result of band migration), and apparently healthy areas of coral tissue in front of the band. The leading and trailing edges of the band were determined based on the presence of apparently healthy coral tissue on one side (leading edge), and exposed coral skeleton on the other side (trailing edge) of samples when imaged.

\section{RESULTS}

Effects of BBD on the integrity of the coral tissue and skeleton were distinct. The imaging techniques employed allowed documentation of relatively intact tissue in the apparently healthy areas of the coral, infiltration of apparently healthy tissue by BBD-associated microorganisms at the band/tissue interface at the leading edge of the band, markedly/completely degraded tissue and skeleton at the interface behind the band, and heavily bored exposed coral skeleton left after band migration.

\section{Leading edge of the BBD mat}

At the base of the leading edge of the BBD mat, cyanobacteria were observed actively boring through the coral skeleton into the overlying coral tissue (Fig. 1A). Examination of tissue which had been peeled back from the underlying skeleton (likely an artifact of the sampling/fixation process) revealed the relationship between the cyanobacteria and the coral tissue and skeleton. In Fig. 1A, numerous cyanobacteria can be seen emerging from within the skeleton and penetrating the overlying tissue. The direction of migration of the cyanobacteria into the overlying tissue is also apparent. Some of the borings observed in the skeleton contained intact cyanobacteria (living at the time of fixation), with some of the filament tips observed to be emerging from the bore holes and broken off in the tissue. Cyanobacteria were also observed migrating between the septae of the coral polyps (Fig. 1B), and appeared to be moving toward the center of the coral polyp. Examination of cross-sections of the cyanobacteria using TEM revealed a radial thylakoid arrangement (Fig. 1C). Filaments were observed to have tapered ends (Fig. 1D), which is characteristic of a cyanobacterium that is the most prevalent cyanobacterium in BBD (Rützler \& Santavy 1983).

Ahead of the migrating band, in an area of apparently healthy, intact coral tissue, small (typically $\sim 0.5 \mu \mathrm{m}$ in width) groups of filamentous bacteria were observed to penetrate the coral tissue through the calicoblastic epithelium, the gastrodermis, and the mesoglea (Fig. 2A). Closer to the band, degraded coral tissue, distinguished by vacuolated columnar cells of the epidermis and exposed zooxanthellae on the surface of the gastrodermis, were observed. In these locations, cyanobacterial filaments $(4 \mu \mathrm{m}$ in width) were observed in the mesoglea 

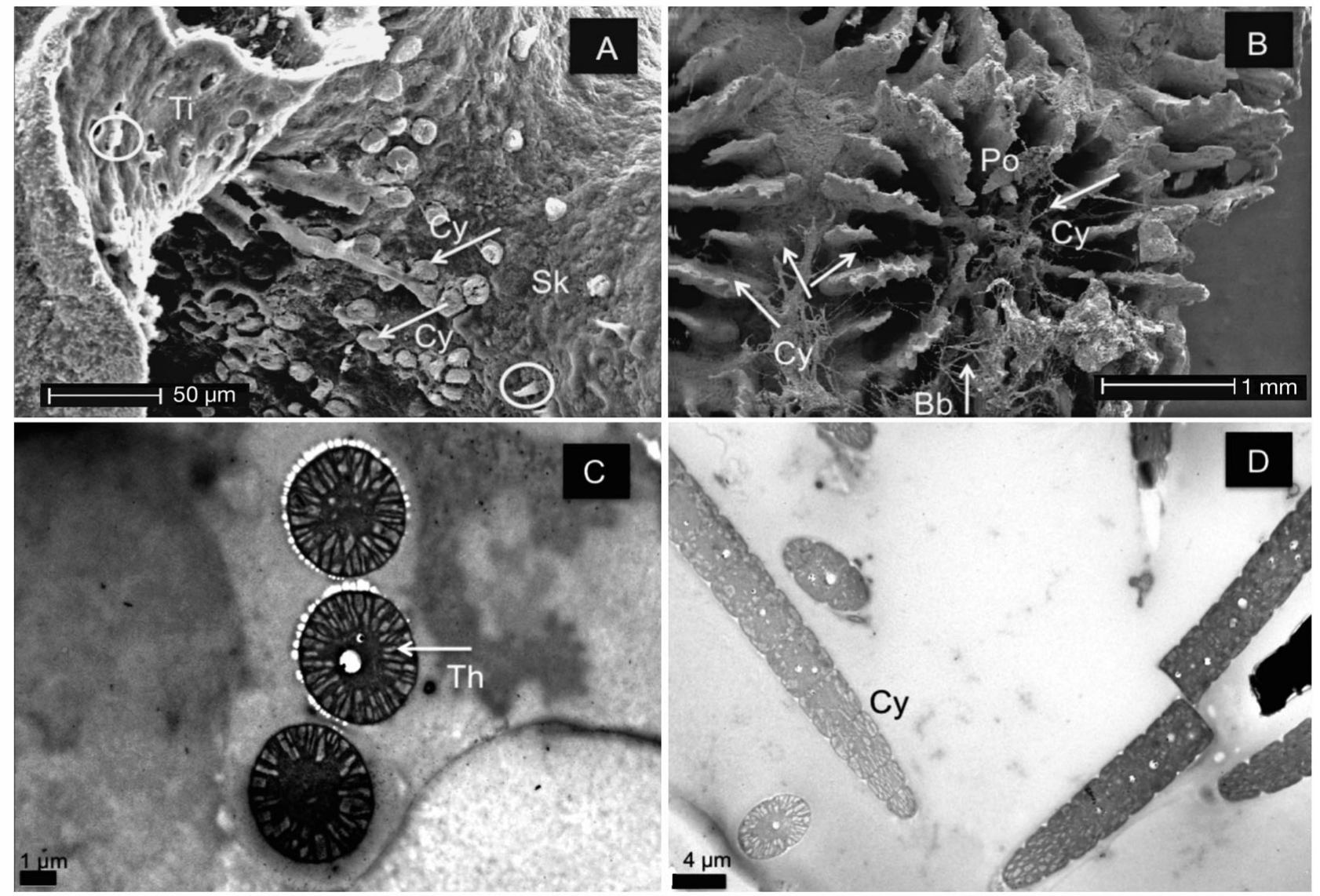

Fig. 1. $(A, B)$ Scanning electron microscopy (SEM) and (C,D) transmission electron microscopy (TEM) images of black band disease (BBD)-infected fragments at the leading edge of the BBD mat. (A) Cyanobacteria (indicated by the arrows) emerging from within the coral skeleton. Circle (bottom right) of the micrograph indicates the tip of a cyanobacterium emerging from the skeleton. Circle (top left) indicates a partial (broken) filament inside the coral tissue. (B) Cyanobacteria migrating in between the septae of the coral polyp. Arrows indicate the direction of movement. (C) Cross-section of cyanobacteria in the BBD mat showing the thyllakoid arrangement within the filaments. (D) Longitudinal section of cyanobacterial filaments in the BBD mat showing the characteristic tapered end. Ti: coral tissue; Cy: cyanobacteria; Sk: coral skeleton; Po: coral polyp; Bb: black band; Th: thylakoids

(Fig. 2B). Within BBD-infected tissue, cyanobacteria were observed in the gastrodermis, mesoglea, and epidermis (Fig. 2C). The migration of the relatively large cyanobacteria through the mesoglea appeared to assist in the degradation and separation of the coral tissue. Greater numbers of cyanobacteria were observed underneath the coral tissues just ahead of the welldefined mat (Fig. 2D). In this image, the BBD mat, consisting primarily of cyanobacteria, can be seen behind the coral tissue. Cyanobacteria were commonly seen underneath apparently healthy tissue up to several millimeters ahead of the advancing band.

\section{Fine-structure of the BBD mat and infected coral tissue}

Relatively large populations of cyanobacteria were observed in coral tissue layers associated with the advancing front of the band (Fig. 3A). In this figure, significant degradation of the coral tissue is visible, apparent from extracellular zooxanthellae in the background, and the lack of intact coral tissue. The thin filamentous microbes observed to be infiltrating intact tissue in the apparently healthy area in front of the band (Fig. 2A) were intermixed with the cyanobacterial filaments in the leading edge of the band. In some cases, these thin filamentous microbes were associated with the breakdown of the coral epidermis (Fig. 3B). The gastrodermis also exhibited some degradation, and extracellular zooxanthellae were exposed.

In some areas, the epidermis was separated from the gastrodermis and appeared to be sloughed off, forming rolled bundles ahead of the migrating band. The formation of bundles ahead of the well-defined mat is likely due to the fact that the healthy epidermis in front of the advancing band is anchored to the rest of the coral tissue (Fig. 3C). In some cases, abundant rolled 

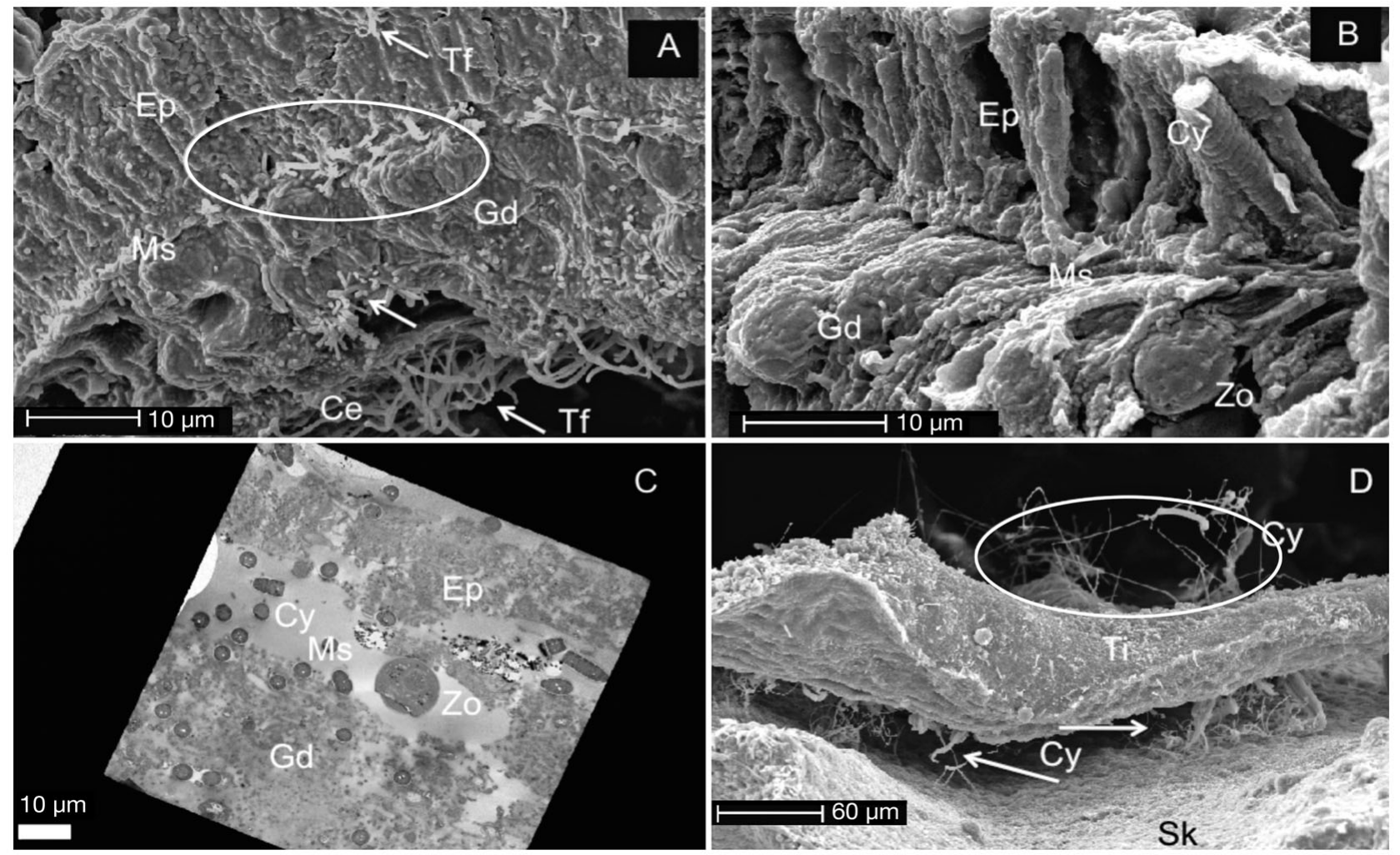

Fig. 2. $(A, B, D)$ SEM and (C) TEM images of black band disease (BBD)-infected coral fragments at the leading edge of the BBD mat. (A) Filamentous bacteria in the epithelium, mesoglea, and gastrodermis preceding the main band. Arrows indicate filaments. Ellipse encloses filaments in the mesoglea. (B) Cyanobacterium present in the mesoglea and epithelium. (C) Cyanobacteria in the gastrodermis, mesoglea, and epithelium. (D) Cyanobacteria migrating underneath coral tissue (arrows) ahead of the main band (ellipse in background). Ep: epidermis; Tf: thin, filamentous microbes; Gd: gastrodermis; Ce: calicoblastic epithelium; Ms: mesoglea; Zo: zooxanthellae; Cy: cyanobacteria

up epidermal bundles were present, found $<1$ to $2.5 \mathrm{~mm}$ ahead of the advancing band. These tissue bundles could be identified as epidermal tissue based on the characteristic intact columnar cells typical of this tissue type (Fig. 3D).

Because of the migration of the cyanobacteria through the mesoglea into the epidermal tissue, the sloughed-off epidermal bundles were infiltrated with cyanobacterial filaments, which were observed to emerge from the bundles (Fig. 4A). The emergence of the cyanobacteria from the epidermal bundles resulted in large numbers of cyanobacteria millimeters ahead of the advancing band.

Small pellet-like structures appeared to form from further degradation of the bundles of epidermis. These structures, which ranged from 15 to $25 \mu \mathrm{m}$ wide and 50 to $90 \mu \mathrm{m}$ long, were commonly present within the BBD mat (Fig. 4B) and were pervasive in all of the infected fragments. Also apparent throughout the mat was a distinct exopolysaccharide (EPS) layer associated with the cyanobacterial filaments (Fig. 4C). Examination of intracellular zooxanthellae within BBDinfected tissues using TEM revealed organelle ultra- structure typical of normal cells. These cells were often observed as doublets, indicative of active cell division (Fig. 4D). Apparently healthy extracellular zooxanthellae were also present (Fig. 5B).

\section{Microbiological aspects of the disease process}

While the overall BBD consortium was clearly dominated by filamentous cyanobacteria, numerous other, smaller, associated bacteria were observed (Fig. 5A) to dominate in some microenvironments of the band. These populations of smaller bacteria included filamentous, rod- and coccoid-shaped morphotypes (Figs. 4B \& 5A). The latter image exhibits an area in which the BBD mat overlay exposed coral skeleton and no coral tissue remained. This area contained fewer cyanobacteria, and the smaller bacteria were present as a biofilm at the base of the band. Since the overall biomass of these microbes was minimal compared to the cyanobacteria, they were a much less conspicuous component of the mat overall. However, they appeared to be important in the final breakdown of the coral 

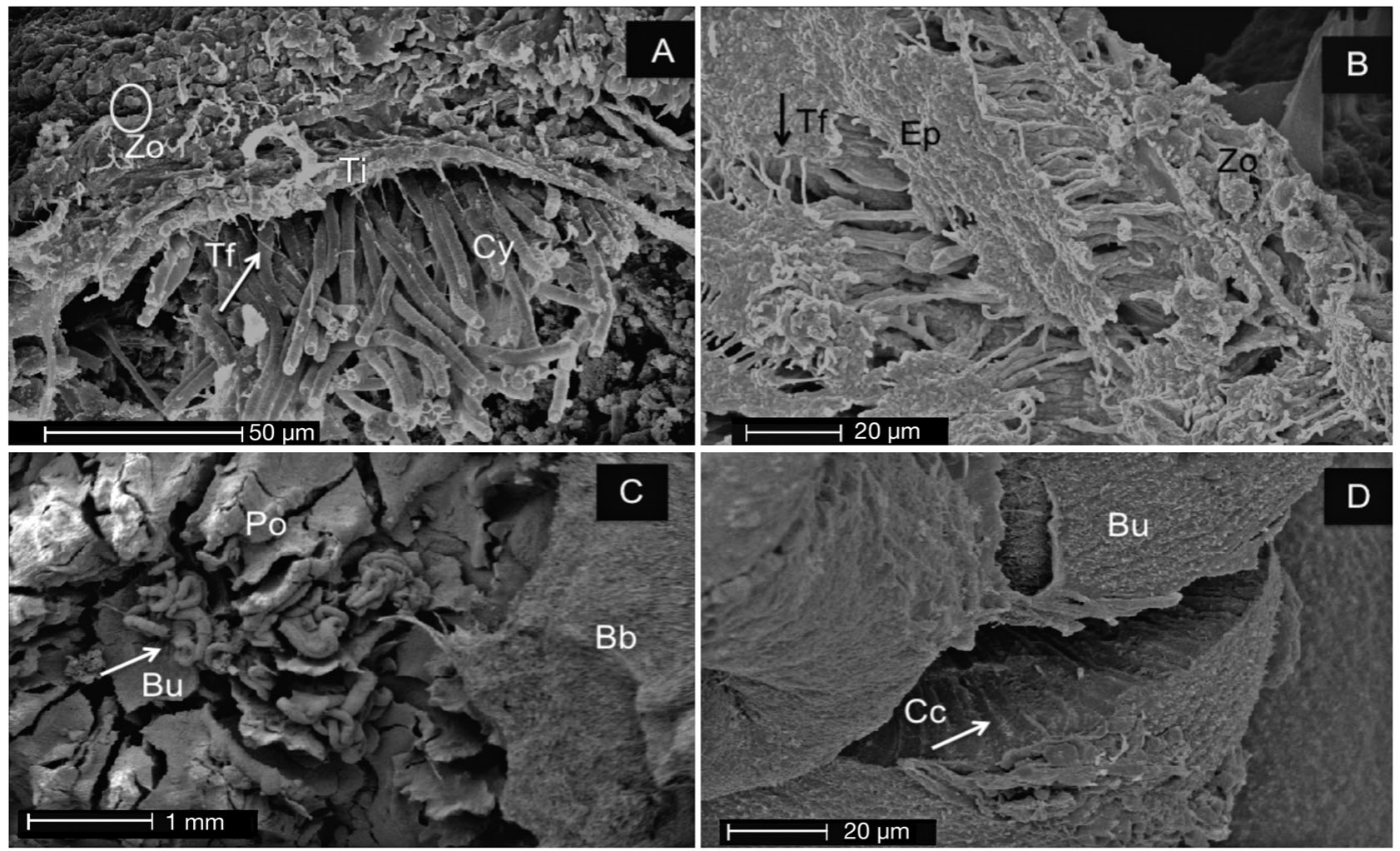

Fig. 3. SEM images of the interface of the black band disease (BBD) mat and apparently healthy tissue. (A) Cyanobacteria and thin filamentous bacteria migrating underneath the coral epidermis at the leading edge of the band (arrow). Extracellular zooxanthellae circled in the background. (B) Degrading coral epidermis with thin filamentous microbes. (C) Sloughed-off bundles of epithelium ahead of the migrating band. (D) Close-up of a break in one of the epidermal bundles. Zo: zooxanthellae; Tf: thin, filamentous microbes; Cy: cyanobacteria; Ti: coral tissue; Ep: coral epidermis; Po: coral polyp; Bu: epidermal bundle; Bb: black

band; Cc: columnar cell

tissue. This is supported by observations that although rod- and coccoid-shaped bacteria were present throughout all areas of the infected fragments, the area left behind after mat migration contained a much greater number of these microbes (Fig. 5A). Degraded tissue was evident in other areas of the trailing end of the mat where zooxanthellae were observed to be present among different filamentous BBD microorganisms (Fig. 5B). In this image, the gastrodermis was completely degraded and the well-defined band overlay exposed coral skeleton.

Filaments among the BBD consortium were often observed to be intertwined, twisted, and had formed loops (Fig. 5C), particularly at the edges of the BBD mat. In some cases, distinct holes were formed within the BBD mat due to the intertwining of several cyanobacterial filaments (Fig. 5D).

Boring activity by the cyanobacteria (Fig. 1A) led to the severe degradation of the coral skeleton, such that numerous bore holes and tracks were present in the exposed skeleton left behind by the migrating band (Fig. 6A). These areas were generally observed in large clusters present on the surface of the exposed skeleton. In addition to the euendolithic cyanobacteria occupying the bored holes (Fig. 1C), numerous chasmoendolithic bacteria were observed (Fig. 6B).

The tissue of the apparently healthy coral (control) fragments was intact (Fig. 6C) and overlay skeleton that exhibited no visible degradation or microbial infiltration comparable to that seen in the BBD-infected coral fragments. While the skeleton of the healthy coral fragment did exhibit borings and tracks that were morphologically similar to those of the infected fragments (Fig. 6D), they were far fewer in number. No cyanobacterial filaments were observed on the coral surface or in the borings of healthy fragments, in contrast to the skeleton of BBD-infected fragments.

\section{DISCUSSION}

\section{Evidence of cyanobacterial boring in BBD}

Our results show that cyanobacteria within the BBD infections examined here are significant borers into and within the coral skeleton, and that these cyano- 

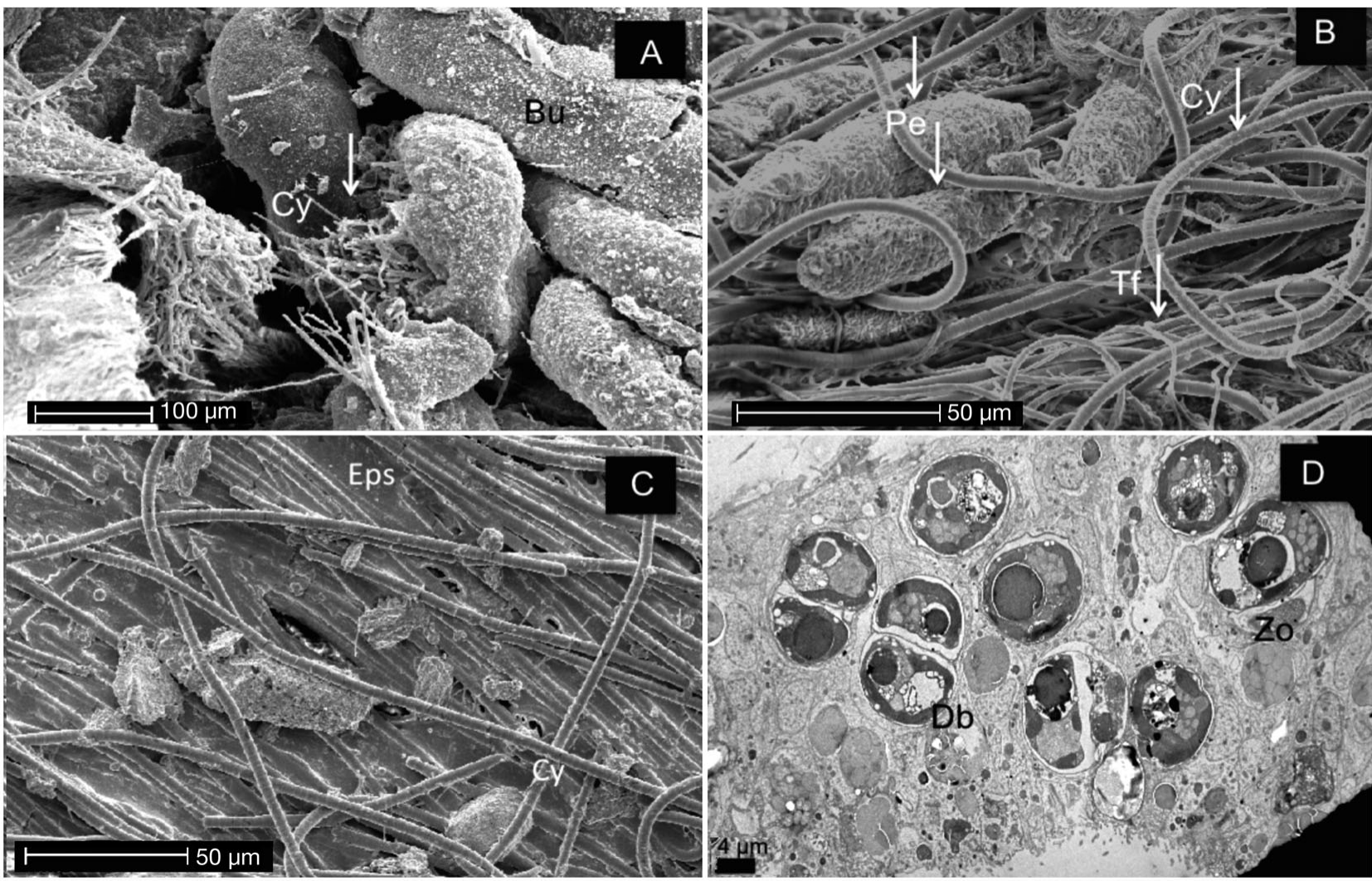

Fig. 4. (A-C) SEM and (D) TEM images of the black band disease (BBD) mat at the coral tissue interface near (A) the front and (B-D) the middle of the band. (A) Cyanobacteria emerging from within a sloughed-off epidermal bundle. (B) The black band mat containing cyanobacteria, thin filamentous bacteria, and small pellets of debris. (C) Cyanobacteria moving in parallel through a distinct exopolysaccharide (EPS) layer. Filaments can be seen migrating on top of and through the EPS layer. (D) TEM section near the interface of the well-defined band and the coral skeleton. Actively dividing zooxanthellae within the BBD-infected tissues are indicated by the high number of dividing cells (doublets). Cy: cyanobacteria; Bu: epidermal bundle; Pe: pellet; Tf: thin, filamentous microbes; Eps: EPS layer; Db: zooxanthellae doublet; Zo: zooxanthellae

bacteria penetrate into coral tissue from the underlying coral skeleton (Fig. 1A). While the penetration of BBD cyanobacteria into coral tissue has been reported previously (Rützler et al. 1983, Barneah et al. 2007, Sato et al. 2009), this is the first observation of BBD cyanobacteria boring into host coral skeleton. This boring behavior is similar to skeletal eroding band, coral disease in the Indo-Pacific that macroscopically appears very similar to BBD, and in which a sessile folliculinid ciliate (Halofolliculina corallasia) directly invades the coral skeleton and in some cases leads to progressive tissue loss (Page \& Willés 2008).

It is well known that boring cyanobacteria make up a significant component of the coral endolithic community, although prior to the current study none have been associated with disease (Le Campion-Alsumard et al. 1995, Radtke et al. 1997, Perry 1998, Vogel et al. 2000, Tribollet \& Payri 2001, Tribollet 2008). In our study, cyanobacterial borings were generally found in large clusters unevenly distributed throughout the exposed coral skeleton of coral fragments infected with BBD (Fig. 6A).
Significant boring was observed both in the artificially infected fragments, which were infected for a period of 2 to $3 \mathrm{~d}$, and naturally occurring diseased colonies with an unknown infection period. There was evidence of boring in the apparently healthy (uninfected) control samples, but it was minimal. This suggests that cyanobacteria present within the band exhibit boring behavior throughout the disease process, and not just as they emerge from within the skeleton. The typical rate of boring is likely slower than the advancement of the disease. However, it is difficult to assess boring rates, and to our knowledge previous studies have only estimated rates of bioerosion from boring $\left(\mathrm{g} \mathrm{CaCO}_{3}\right.$ removed), not boring rates.

The SEM imagery revealed that most of the boring was oriented perpendicular to the coral surface. This observation is consistent with boring of carbonates by other cyanobacteria, which is typically perpendicular rather than parallel to the substrate (Garcia-Pichel 2006). Vertical boring is conducive to a model in which cyanobacteria leave a bore hole as the mat passes overhead and the cyanobacteria are recruited to the 

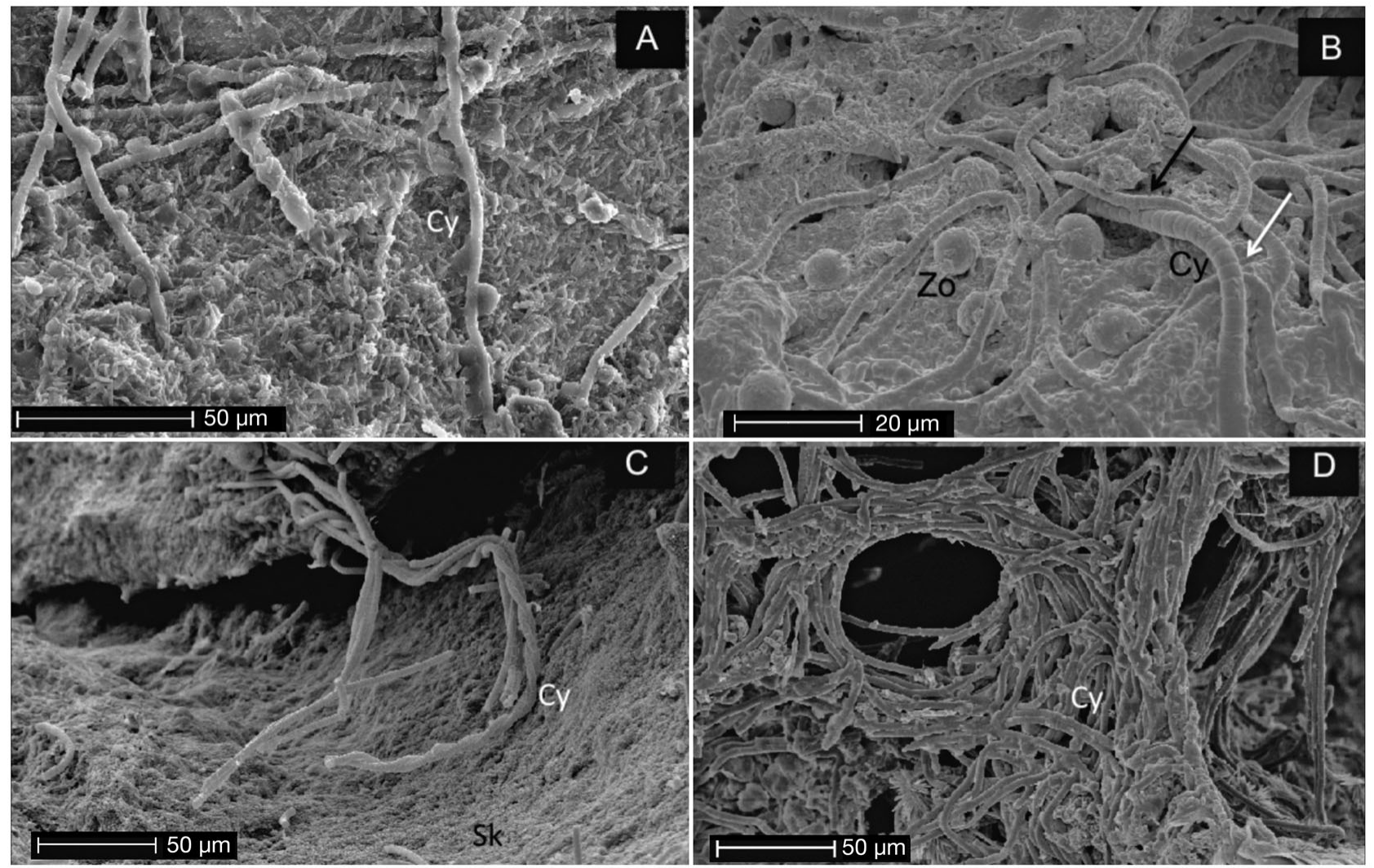

Fig. 5. SEM images $(A, C)$ at the interface between the black band disease (BBD) mat and the exposed coral skeleton and (B,D) near the back of the band. (A) Numerous non-filamentous bacteria associated with cyanobacterial filaments in the BBD mat. (B) Zooxanthellae among the BBD mat cyanobacteria in the degraded gastrodermis. Black arrows indicate potential filamentous sulfide-oxidizing bacteria and white arrows indicate cyanobacteria. (C) Twisting of cyanobacterial filaments creating loops at the periphery of the mat. (D) A distinct hole of intertwined cyanobacterial filaments within the BBD mat. Cy: cyanobacteria;

Zo: zooxanthellae; Sk: coral skeleton

mat, or conversely bore into the skeleton from the mat. While horizontal boring would likely require additional boring through the substrate, and the majority of the boring observed in this study was perpendicular to the substrate, tracks were also observed in coral skeleton that were a result of parallel boring (Fig. 6A).

\section{Detection of a novel population of BBD microorganisms}

SEM revealed consistent populations of small, filamentous microorganisms present within the BBD community. Identification of the taxonomic affiliation of these microorganisms was outside of the scope of this study, but should be targeted in the future. Observation of their presence in association with BBD provides some insight into the disease process. The thin, filamentous microbes were present in the apparently healthy area of the coral tissue immediately in front of the band (Fig. 2A), as well as within the cyanobacterial BBD matrix (Figs. 3A \& 4B), and in degrading epider- mal tissue (Fig. 3B). Based on these observations, these bacteria may be important in the initial breakdown of coral tissue, and may also facilitate the penetration of apparently healthy coral tissue by the much larger cyanobacteria.

\section{Insights into the BBD process}

SEM was useful in characterizing the role of BBD cyanobacteria in the disease process in terms of both infection of apparently healthy coral tissue and breakdown of tissue. In some cases, migration of cyanobacteria across the infected coral caused the epidermis to be completely removed, and in others, the penetration of cyanobacteria through the mesoglea and epidermis appeared to cause the epidermis to slough off in bundles which were packed with cyanobacterial filaments. Within the mat cyanobacteria could be seen as closely associated with extracellular polysaccharide. Such EPS is characteristic of a large number of mat-forming bacteria, including cyanobacteria (Wingender et al. 1999, 


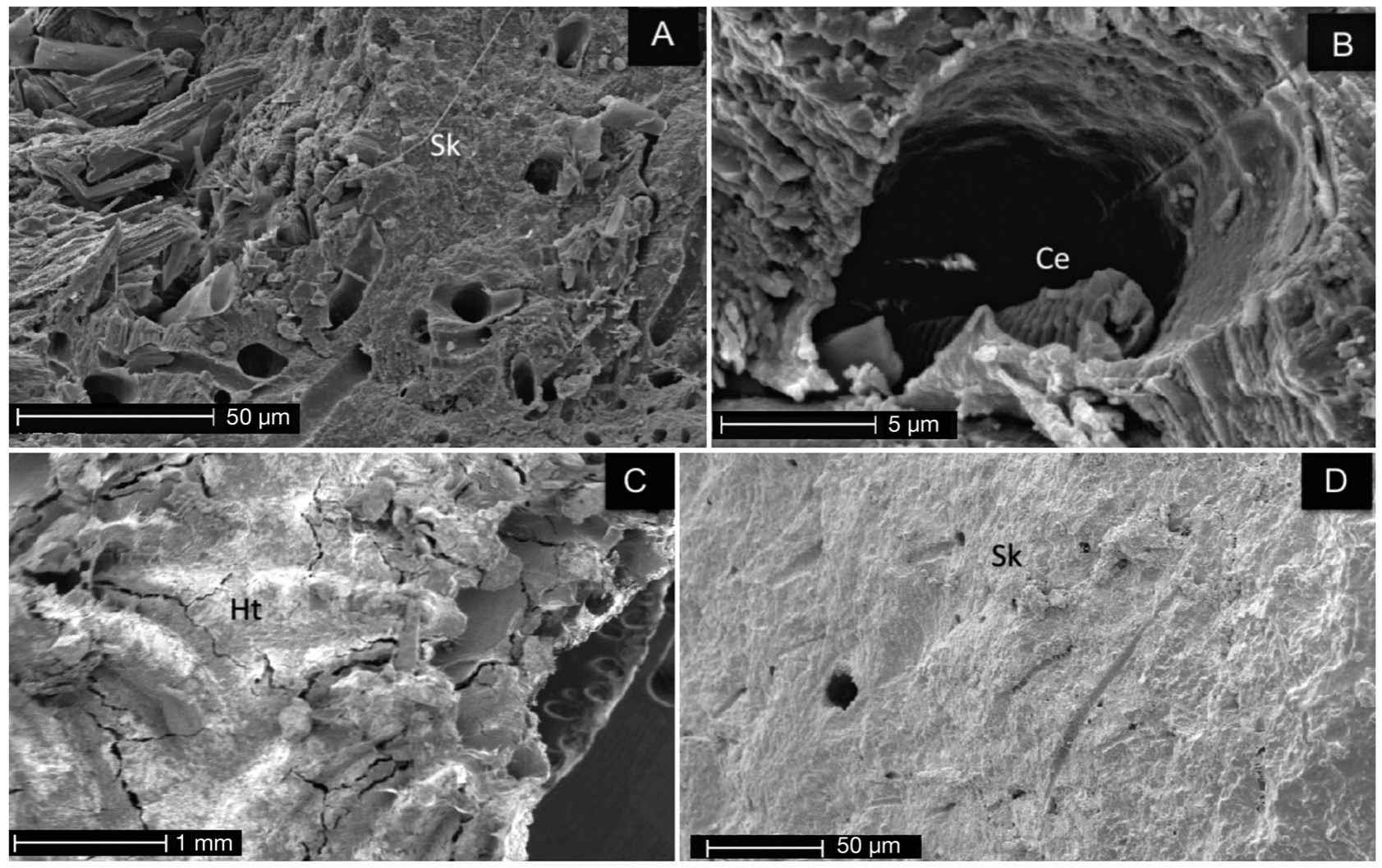

Fig. 6. SEM images comparing the exposed coral skeletons of $(\mathrm{A}, \mathrm{B})$ a black band disease (BBD)-infected fragment behind the mat and $(\mathrm{C}, \mathrm{D})$ an apparently healthy coral. (A) Bore holes in the exposed coral skeleton. (B) Bore hole occupied by a chasmoendolithic filamentous bacterium. (C) Apparently healthy coral fragment exhibiting intact coral tissue overlying the coral skeleton. (D) Bore holes and tracks present on the surface of apparently healthy coral skeleton. Sk: coral skeleton; Ce: chasmoendolith; Ht: healthy tissue

Wolfaardt et al. 1999), and serves as a protective barrier to the external environment (De Philippis \& Vincenzini 1998).

It has been proposed that the physical penetration of coral tissue by BBD cyanobacteria is likely to be preceded and greatly aided by chemical lysis (Rützler et al. 1983). It is now known that the chemical microenvironment of the BBD mat is supersaturated with oxygen during the day near the surface, due to photosynthetic activity of the cyanobacteria, and anoxic deeper in the band where sulfide is present (Carlton \& Richardson 1995). At night, when photosynthesis ceases, the oxygen/sulfide interface migrates vertically outward into the overlying water column, rendering the entire mat anoxic and sulfide rich. It has also been determined experimentally that exposure of corals to sulfide at a concentration present in the mat results in lysis of coral tissue within $17 \mathrm{~h}$ (Richardson et al. 1997). Microcystin, a cyanotoxin, has been detected in BBD and is produced by BBD-associated cyanobacteria in culture in the laboratory (Richardson et al. 2007, Gantar et al. 2009). It has recently been shown that exposure of healthy coral fragments to purified microcystin causes severe degradation of the epidermis and gastrodermis of corals over a similar timeframe, an effect which is exacerbated in combination with exposure to sulfide (Richardson et al. 2009). The degradation of the epidermis and gastrodermis in BBD-infected fragments in the current study appears to be very similar to that of tissue degraded by exposure to microcystin and sulfide (Richardson et al. 2009), which supports the hypothesis of chemical degradation put forth by Rützler et al. (1983). However, it has been shown that not all BBD infections produce microcystin (Glas et al. 2010), adding to the complexity of this disease.

The observation of intact, dividing zooxanthellae within the BBD cyanobacterial matrix suggests that they too may be affected by the sulfidic and potentially toxic BBD environment. Active zooxanthellae division and expulsion have previously been documented in corals exposed to cyanide (Cervino et al. 2003), suggesting that the zooxanthellae observed in the present study may be undergoing similar stress levels related to exposure to the chemical microenvironment within the disease band. 
Epidermal tissue bundles observed during disease progression were always present ahead of the welldefined band. This was likely due to the fact that the invaded tissue was contiguous with the apparently healthy tissue in front of the band (Fig. 3C). Cyanobacteria could be seen emerging from these bundles, ahead of the forward edge of the mat. Large pellets (Fig. 4B), pervasive throughout all of the BBD samples, were likely the remnants of the epidermal bundles, a result of progressive degradation as the BBD mat passed over them.

The motility patterns exhibited by the BBD cyanobacteria are typical of other cyanobacterial and filamentous bacterial mats. For example, the twisting of filaments and formation of loops found in the band is indicative of negative taxis in gliding, filamentous microorganisms (Møller et al. 1985). In the current study, the twisting of filaments occurred at the edges of the cyanobacteria-dominated mat, suggesting that a chemical or light gradient determined the mat-forming behavior of the BBD cyanobacteria. In addition, the parallel migration of cyanobacterial filaments in the BBD mat suggests a migration toward or away from an environmental cue.

Filamentous, mat-forming cyanobacteria generally do not tolerate high light levels, and self-shade or migrate to light levels more attuned to their light-saturated photosynthetic rate $\left(P_{\max }\right)$ (Castenholz 1982, Castenholz et al. 1991, Garcia-Pichel et al. 1994). It has been demonstrated that the cyanobacterial population, which exhibits a dark red-black color and is normally on the surface of BBD (and the reason for the name of the disease), moves down into the mat during high light levels and is replaced on the surface by a population of white, gliding, sulfide-oxidizing BBD microorganisms (Beggiatoa sp.) (Richardson 1996, Viehman \& Richardson 2002). This is the opposite of cyanobacterial/Beggiatoa vertical migrations in other sulfide-rich, illuminated microbial mats (Jørgensen et al. 1979, Jørgensen 1982). It may be that BBD cyanobacteria at the front of the band migrate into the tissue to attain optimal (relatively lower) light levels. This is consistent with this and a previous study that found cyanobacteria tunneling in a parallel configuration beneath the epidermis ahead of the mat (Rützler et al. 1983). In another study, it was found that 2 cyanobacterial isolates from BBD, Geitlerinema sp. and Leptolyngbya sp., attained $P_{\max }$ at relatively low light levels of 81 and $108 \mu \mathrm{E} \mathrm{m}^{-2}$, respectively (Myers et al. 2007). It has also been shown in situ that cyanobacterial migration down into the mat occurs when light levels reach $238 \mu \mathrm{E} \mathrm{m} \mathrm{m}^{-2}$ $\mathrm{s}^{-1}$ (Viehman \& Richardson 2002). This discussion does not rule out the possibility that chemotaxis may play a role in migration, an aspect of BBD etiology that is completely unknown.
It is not clear from the current analysis whether the well-defined migrating band follows the pioneering groups of cyanobacteria, or whether the advancement of the band is the result of a high turnover rate of the consortium based on rapid growth of the advancing filaments. It is also not known whether a large number of cyanobacteria from the main band die or retreat into the coral skeleton by boring activity. The observed behavior of migration toward the gastrovascular cavity through the polyp suggests that retreat into the skeleton during the disease process occurs to some extent. The boring behavior of the cyanobacteria may provide a significant advantage in that the coral skeleton may serve as a reservoir of pathogenic cyanobacteria that persist in low numbers even as disease signs disappear in cooler seasons. When more favorable (warmer) conditions resume, the cyanobacterial numbers may again increase and reinfect the coral. Such reoccurrence of BBD on the same corals in subsequent disease seasons has been observed previously (Kuta \& Richardson 1997, Sato et al. 2009). It is likely that both the advancement of the intact band following the pioneering cyanobacteria and the retreat or die-off of some filaments occur to some extent.

\section{Coral skeleton as a reservoir for BBD cyanobacteria}

The hypothesis that the coral skeleton harbors a reservoir of cyanobacteria associated with BBD could be tested by comparing the endolithic cyanobacterial community of BBD-infected corals to the cyanobacterial community in the BBD infection, and to that of the endolithic community of apparently healthy coral colonies using both molecular and culturing techniques. This would require sampling the same corals in both disease and non-disease seasons. If the coral skeleton harbored the cyanobacteria associated with BBD, it is expected that the endolithic community should have similar cyanobacteria to the BBD community.

Sato et al. (2009) found that non-BBD cyanobacterial patches that were present on some coral colonies occasionally (19\% of the time) shifted from a Blenothrix sp.dominated mat to a mat dominated by the most prevalent cyanobacterium found globally in BBD, most closely related to Oscillatoria. It is possible that the transition from cyanobacterial patches to BBD was based on movement of BBD cyanobacteria from host skeletal reservoirs, resulting in replacement of Blenothrix sp. as the dominant cyanobacterium.

\section{SUMMARY}

BBD is one of the first coral diseases reported and is considered among the most ecologically important 
diseases affecting coral reefs. We now know that it consists of a highly variable, complex consortium of microbes. While the mechanisms behind the infection process and pathobiology of BBD are still not completely understood, the results of the current analysis introduce several new insights into this disease. First, the filamentous, gliding cyanobacteria that are associated with the disease actively bore through both the host coral skeleton and tissue, indicating a potential natural reservoir of the disease. Second, coral tissue lysis and degradation appear to be aided by the physical movement of cyanobacteria through the tissue layers in front of the migrating band. Finally, a novel population of small, as yet unidentified, filamentous bacteria was observed throughout (before, within, and behind) BBD. The presence of these bacteria throughout the disease, including in actively degrading epidermis, suggests that this population may be important in the complete lysis and removal of coral tissue characteristic of this coral disease.

Acknowledgements. We thank J. Voss and S. Edge for their help in providing samples for this analysis as well as the Perry Institute for Marine Science, which provided access to the research station in Lee Stocking Island, Bahamas. Sample collection in the Florida Keys National Marine Sanctuary was conducted under permit number FKNMS-2007-026, and at Lee Stocking Island, Bahamas, under permit number CMRC04- PRJV-01-04C. J. Prince kindly allowed us use of the TEM in the Biology Department at the University of Miami. This is contribution number 192 from the Tropical Biology Program at Florida International University.

\section{LITERATURE CITED}

Aeby G, Santavy D (2006) Factors affecting susceptibility of the coral Montastraea faveolata to black band disease. Mar Ecol Prog Ser 318:103-110

Arotsker L, Siboni N, Ben-Dov E, Kramarsky-Winter E, Loya Y, Kushmaro A (2009) Vibrio sp. as a potentially important member of the Black Band Disease (BBD) consortium in Favia sp. corals. FEMS Microbiol Ecol 70:515-524

Barneah O, Ben-Dov E, Kramarsky-Winter E, Kushmaro A (2007) Characterization of black band disease in Red Sea stony corals. Environ Microbiol 9:1995-2006

Bythell JC, Pantos O, Richardson LL (2004) White plague, white band, and other 'white' diseases. In: Rosenberg E, Loya Y (eds) Coral health and disease. Springer-Verlag, Berlin, p 351-363

Carlton RG, Richardson LL (1995) Oxygen and sulfide dynamics in a horizontally migrating cyanobacterial mat: black band disease of corals. FEMS Microbiol Ecol 18: 155-162

Castenholz RW (1982) Motility and taxes. In: Carr NG, Whitten BA (eds) Biology of cyanobacteria. Blackwell Scientific Publications, Oxford, p 414-439

> Castenholz RW, Jørgensen BB, D'Amelio E, Bauld J (1991) Photosynthetic and behavioral versatility of the cyanobacterium Oscillatoria boryana in sulfide-rich microbial mat. FEMS Microbiol Ecol 86:43-48

> Cervino JM, Hayes RL, Honovich M, Goreau TJ, Jones S, Rubec PJ (2003) Changes in zooxanthellae density, mor- phology, and mitotic index in hermatypic corals and anemones exposed to cyanide. Mar Pollut Bull 46:573-586

Cooney R, Pantos M, Le Tissier M, Rarer A, O'Donnell A, Bythell J (2002) Characterization of the bacterial consortium associated with black band disease in coral using molecular microbiological techniques. Environ Microbiol 4:401-413

De Philippis R, Vincenzini M (1998) Exocellular polysaccharides from cyanobacteria and their possible applications. FEMS Microbiol Rev 22:151-175

> Ducklow H, Mitchell R (1979) Observations on naturally and artificially diseased tropical corals: a scanning electron microscope study. Microb Ecol 5:215-223

Frias-Lopez J, Zerkle A, Bonheyo G, Fouke B (2002) Partitioning of bacterial communities between seawater and healthy, black band diseased, and dead coral surfaces. Appl Environ Microbiol 68:2214-2228

Frias-Lopez J, Bonheyo G, Qusheng J, Fouke B (2003) Cyanobacteria associated with coral black band disease in Caribbean and Indo-Pacific reefs. Appl Environ Microbiol 69:2409-2413

Gantar M, Sekar R, Richardson LL (2009) Toxicity of culturable cyanobacteria associated with black band disease of corals. Microb Ecol 58:856-864

> Garcia-Pichel F (2006) Plausible mechanisms for the boring on carbonates by microbial phototrophs. Sediment Geol 185:205-213

Garcia-Pichel F, Mechling M, Castenholz RW (1994) Diel migrations of microorganisms within a benthic, hypersaline mat community. Appl Environ Microbiol 60: $1500-1511$

Glas M, Motti C, Negri A, Sato Y and others (2010) Cyanotoxins are not implicated in the etiology of coral black band disease outbreaks on Pelorus Island, Great Barrier Reef. FEMS Microbiol Ecol 73:1-12

Jones RJ, Bowyer J, Hoegh-Guldberg O, Blackall LL (2004) Dynamics of a temperature-related coral disease outbreak. Mar Ecol Prog Ser 281:63-77

> Jørgensen B (1982) Ecology of the bacteria of the sulfur cycle with special reference to anoxic-oxic interface environments. Philos Trans R Soc Lond B Biol Sci 298:543-561

Jørgensen BB, Blackburn TH, Cohen Y (1979) Diurnal cycle of oxygen and sulfide microgradients and microbial photosynthesis in a cyanobacterial mat sediment. Appl Environ Microbiol 38:46-58

Kaczmarsky L, Draud M, Williams E (2005) Is there a relationship between proximity to sewage effluent and the prevalence of coral disease? Caribb J Sci 41:124-137

Kuta K, Richardson LL (1997) Black band disease and the fate of diseased corals in the Florida Keys. Proc 8th Int Coral Reef Symp 1:575-578

> Le Campion-Alsumard T, Golubic S, Hutchings P (1995) Microbial endoliths in skeletons of live and dead corals: Porites lobata (Moorea, French Polynesia). Mar Ecol Prog Ser 117:149-157

Miller AW, Richardson LL (2011) A meta-analysis of 16S rRNA gene clone libraries from the polymicrobial black band disease of corals. FEMS Microbiol Ecol 75:231-241

> Møller M, Nielsen L, Jørgensen B (1985) Oxygen responses and mat formation by Beggiatoa spp. Appl Environ Microbiol 50:373-382

- Myers J, Richardson LL, Sekar R (2007) Molecular detection and ecological significance of the cyanobacteria Geitlerinema and Leptolyngbya in black band disease of corals. Appl Environ Microbiol 73:5173-5182

> Page CA, Willis BL (2008) Epidemiology of skeletal eroding band on the Great Barrier Reef and the role of injury in the 
initiation of this widespread coral disease. Coral Reefs $27: 257-272$

Perry C (1998) Grain susceptibility to the effects of microboring: implication for the preservation of skeletal carbonates. Sedimentology 45:39-51

Radtke G, Le Campion-Alsumard T, Golubic S (1997) Microbial assemblages involved in tropical coastal bioerosion: an Atlantic-Pacific comparison. Proc 8th Int Coral Reef Symp Panama 2:1825-1830

Reynolds ES (1963) The use of lead citrate at high $\mathrm{pH}$ as an electron-opaque stain in electron microscopy. J Cell Biol $17: 208-212$

Richardson LL (1996) Horizontal and vertical migration patterns of Phormidium corallyticum and Beggiatoa spp. associated with black band disease of corals. Microb Ecol 32:323-335

Richardson LL (1997) Occurence of the black band disease cyanobacterium on healthy corals of the Florida Keys. Bull Mar Sci 61:485-490

Richardson LL, Aronson R (2002) Infectious diseases of reef corals. Proc 9th Int Coral Reef Symp 2:1225-1230

Richardson LL, Kuta K, Schnell S, Carlton R (1997) Ecology of the black band disease microbial consortium. Proc 8th Int Coral Reef Symp 1:597-600

Richardson LL, Sekar R, Myers J, Gantar M and others (2007) The presence of the cyanobacterial toxin microcystin in black band disease of corals. FEMS Microbiol Ecol 272: 182-187

Richardson LL, Miller A, Broderick E, Kaczmarsky L, Gantar M, Stanic D, Sekar R (2009) Sulfide, microcystin, and the etiology of black band disease. Dis Aquat Org 87: 79-90

Rosenberg E, Kushmaro A, Kramarsky-Winter E, Banin E, Loya Y (2009) The role of microorganisms in coral bleaching. ISME J 3:139-146

Rützler K, Santavy D (1983) The black band disease of Atlantic reef corals. PSZN I: Mar Ecol 4:301-319

Rützler K, Santavy D, Antonius A (1983) The black band disease of Atlantic reef corals III: distribution, ecology, and development. PSZN I: Mar Ecol 4:329-358

Editorial responsibility: Garriet Smith, Aiken, South Carolina, USA
Rypien KL, Ward JR, Azam F (2010) Antagonistic interactions among coral-associated bacteria. Environ Microbiol 12: 28-39

Sato Y, Willis BL, Bourne DG (2009) Successional changes in bacterial communities during the development of black band disease on the reef coral, Montipora hispida. ISME J $4: 203-214$

Sekar R, Kaczmarsky LT, Richardson LL (2008) Microbial community composition of black band disease on the coral host Siderastrea siderea from three regions of the wider Caribbean. Mar Ecol Prog Ser 362:85-98

Sussman M, Bourne DG, Willis BL (2006) A single cyanobacterial ribotype is associated with both red and black bands on diseased corals from Palau. Dis Aquat Org 69:111-118

Tribollet A (2008) The boring microflora in modern coral reef ecosystems: a review of its roles. In: Wisshak M, Tapanila L (eds) Current developments in bioerosion. Erlangen Earth Conf Ser. Springer Verlag, Heidelberg, p 67-94

Tribollet A, Payri C (2001) Bioerosion of the crustose coralline alga Hydrolithon onkodes by microborers in the coral reefs of Moorea, French Polynesia. Oceanol Acta 24: $329-342$

Viehman TS, Richardson LL (2002) Motility patterns of Beggiatoa and Phormidium corallyticum in black band disease. Proc 9th Int Coral Reef Symp 2:1251-1255

Vogel K, Gektidis M, Golubic S, Kiene WE, Radtke G (2000) Experimental studies on microbial bioerosion at Lee Stocking Island, Bahamas, and One Tree Island, Great Barrier Reef, Australia: implications for paleoecological reconstructions. Lethaia 33:190-204

Voss J, Richardson LL (2006) Nutrient enrichment enhances black band disease progression in corals. Coral Reefs 25:569-576

Wingender J, Neu T, Flemming H (1999) What are bacterial extracellular polymeric substances? In: Wingender J, Neu $\mathrm{T}$, Flemming $\mathrm{H}$ (eds) Microbial extracellular polymeric substances. Springer, Berlin, p 1-19

Wolfaardt G, Lawerence J, Korber D (1999) Function of EPS. In: Wingender J, Neu T, Flemming H (eds) Microbial extracellular polymeric substances. Springer, Berlin, p 171-200

Submitted: June 30, 2010; Accepted: October 25, 2010

Proofs received from author(s): February 15, 2011 